US Army Corps

of Engineers $S_{\circledast}$

Engineer Research and

Development Center

\title{
Influences of $U$ Sources and Forms on Its Bioaccumulation in Indian Mustard and Sunflower
}

Fande Meng, Decheng Jin, Kai Guo, Steven L. Larson, John H. Ballard,

Liangmei Chen, Zikri Arslan, Guodong Yuan, Jeremy R. White, Lixiang Zhou,

Youhua Ma, Charles A.Waggoner, and Fengxiang X. Han 
The U.S. Army Engineer Research and Development Center (ERDC) solves the nation's toughest engineering and environmental challenges. ERDC develops innovative solutions in civil and military engineering, geospatial sciences, water resources, and environmental sciences for the Army, the Department of Defense, civilian agencies, and our nation's public good. Find out more at www.erdc.usace.army.mil.

To search for other technical reports published by ERDC, visit the ERDC online library at http://acwc.sdp.sirsi.net/client/default. 


\section{Influences of $\mathbf{U}$ Sources and Forms on Its Bioaccumulation in Indian Mustard and Sunflower}

Steven L. Larson and John H. Ballard

Environmental Laboratory

U.S. Army Engineer Research and Development Center

3909 Halls Ferry Road

Vicksburg, MS 39180

Fende Meng, Decheng Jin, Kai Guo, Liangmei Chen, Zikri Arslan, Jeremy R. White, Fengxiang X. Han

Department of Chemistry and Biochemistry

Jackson State University

Jackson, MS 39217

Lixiang Zhou and Youhua Ma

College of Environmental Sciences

Nanjing Agricultural University

Nanjing 210095, China

Charles A. Waggoner

Institute for Clean Energy Technology

Mississippi State University

Starkville, MS 39759

Final report

Approved for public release; distribution is unlimited.
Guodong Yuan

Environmental and Chemical Engineering

Zhaoqing University

Zhaoqing 526061, China

Prepared for U.S. Army Corps of Engineers

Washington, DC 20314

Under Project Number 458170, “Depleted Uranium (DU) Clearance from DoD Ranges" 


\section{Abstract}

Anthropogenic activities, such as ore mining and processing, nuclear power generation, and weapon tests, have generated uranium (U) contamination to soils and waters. The mobility and bioavailability of $U$ are influenced by its sources, speciation, and plant species. Phytoremediation has emerged as an environmentally friendly, cost-effective green technology to remediate radioisotope-and metal contaminated soils. The main objective of this study was to explore the feasibility using sunflower (Helianthus annuus) and Indian mustard (Brassica juncea) in cleaning up soils with $\mathrm{UO} 2, \mathrm{UO}_{3}$, and $\mathrm{UO} 2\left(\mathrm{NO}_{3}\right)_{2}$. Uranium was found to be bioaccumulated in plant roots more than plant shoots. Uranium uptake by both plant species was significantly higher from the $\mathrm{UO}_{3}$ - and uranyl-contaminated soils than from $\mathrm{UO}_{2}$ - contaminated soils. $\mathrm{UO}_{3}$ - and $\mathrm{UO}_{2}\left(\mathrm{NO}_{3}\right)_{2}$-contaminated soils showed higher exchangeable, weak acid extractable, and labile $U$ than the UO2-contaminated soils. After a growing season, three U forms decreased as redistribution/transformation of $U$ resulted in $U$ species with lower extractability. This study indicates the importance of $U$ speciation in soil with regard to the potential use of sunflower and Indian mustard for phytoremediation of U-contaminated soils.

DISCLAIMER: The contents of this report are not to be used for advertising, publication, or promotional purposes. Citation of trade names does not constitute an official endorsement or approval of the use of such commercial products. All product names and trademarks cited are the property of their respective owners. The findings of this report are not to be construed as an official Department of the Army position unless so designated by other authorized documents. 


\section{Preface}

This study was conducted for the U.S. Army Corps of Engineers under Project 458170, titled, "Depleted Uranium (DU) Clearance from DoD Ranges." The Grant Officer's Technical Representative was Mr. John H. Ballard, Office of the Technical Director for Installations and Operational Environments, ERDC-EL-EZT and the Technical Point of Contact was Dr. Steven L. Larson, Environmental Engineering Branch, ERDC-EL-EPE.

The work was performed by the Environmental Engineering Branch of the Environmental Processes Division, U.S. Army Engineer Research and Development Center, Environmental Laboratory (ERDC-EL). At the time of publication of this Miscellaneous Paper, Ms. Brooke Petery was Acting Branch Chief; Dr. Brandon Lafferty was Acting Division Chief; and Dr. Elizabeth Ferguson was the Technical Director for Installations and Operational Environments. The Acting Deputy Director of ERDC-EL was Dr. Justin Berman and the Acting Director was Dr. Jack Davis.

This report documents a collaborative study conducted under the sponsorship of the U.S. Army Futures Command with FY18 Congressional Program Increase Funds in PE 0603728A in the Fiscal Year (FY) 2018 Department of Defense Appropriations Act. Collaborative work was conducted by the U.S. Army Engineer Research and Development Center and Jackson State University via Cooperative Agreement W912HZ-16-2-0021.

The Commander of ERDC was COL Teresa A. Schlosser and the Director was Dr. David W. Pittman. 


\section{Introduction}

Uranium (U) is a naturally occurring toxic heavy metal widely found in soil environment. Radioactivity of $U$ is a result of decay process for three $U$ isotopes (U-238, U-235, and U-234). Its concentration in soil varies from 0.3 to $11.7 \mathrm{mg} / \mathrm{kg}$, with an average of 2.6 $\mathrm{mg} / \mathrm{kg}$ (Rankin 2008). The presence of mobile, labile and bioavailable $U$ in soil at levels of significant environmental risks is mainly caused by anthropogenic activities, such as ore mining waste, nuclear power waste, and weapon testing. Soil areas with $\mathrm{U}$ may reach high levels of $100 \mathrm{of} \mathrm{mg} / \mathrm{kg}$ and even more than $1000 \mathrm{mg} / \mathrm{kg}$ (Larson et al. 2009; Tuovinen et al. 2015; Liu et al. 2017; Dang et al. 2018). For example, $\mathrm{U}$ concentrations in sediments from gold mining in South Africa were more than $100 \mathrm{mg} / \mathrm{kg}$ in average, reaching up to $1000 \mathrm{mg} / \mathrm{kg}$ and $\mathrm{U}$ concentration in surface waters was significantly higher than that in the flowing water into the tailing (Winde and van der Walt 2004).

Uranium poses chemical and biological toxicity. Uranium in soils may be bioaccumulated in plants, posing risks to human health through food chains, such as increasing risks of cancer, kidney toxicity, and birth defect rates (Fetter and von Hippel 2000; Fathi et al. 2013). The mobility of $U$ in soil is significantly related to its speciation and sources (Radenković et al. 2008). In soil environment, $U$ is present usually as $U(I V)$ and $\mathrm{U}(\mathrm{VI})$ and hexavalent $\mathrm{U}$ is the main form under oxidizing conditions. In reducing environments, the predominant, reduced form, U(IV), forms highly insoluble phases as $\mathrm{UO}_{2}\left(\log K_{\mathrm{sp}}=-53.93 \pm 0.2\right)$ reducing its mobility and bioavailability (Fujiwara et al. 2003; Abdelouas 2006). However, the reduced form may be transformed to U(VI) under oxidizing conditions in presence of electron acceptors, such as humic substances and Fe(III) (Gu et al. 2005; Sani et al. 2005). Uranium in soil interacts with soil components, such as Fe-Mn oxides, carbonate, organic matter and clay minerals, to form different $U$ complexes with a range of mobility and bioavailability, which in turn influences its redistribution in soil and its uptake by plants (Bednar et al. 2007; Vandenhove et al. 2007; Dang et al. 2016).

The accumulation and distribution of $U$ in plants was reported and shown to be influenced by its speciation in soil (Duquène et al. 2009; Véra-Tome et al. 2009; Laurette et al. 2012a, 2012b; Jagetiya and Sharma 2013; Cordeiro et al. 2016; Favas et al. 2016). Sunflower (Helianthus annuus) accumulated $\mathrm{U}$ mainly in roots, especially the ionic $\mathrm{UO}_{2}{ }^{2+}$ (Laurette et al. 2012a; VéraTome et al. 2008). Due to high accumulation, Indian mustard (Brassica juncea) has been used for phytoremediation of many toxic metals including $\mathrm{U}$ in contaminated soil (Qi et al. 2014; Choudhury et al. 2016). A number of studies showed that the phytoremediation of $U$ was enhanced with adding soil amendments (Duquène et al. 2009; Jagetiya and Sharma 2013). However, effects of $U$ forms in soils on its bioaccumulation in plants are not fully understood (Alsabbagh and Abuqudaira 2017).

The objectives of the present study were (1) to examine the effect of $\mathrm{U}$ sources $\left(\mathrm{UO}_{2}, \mathrm{UO}_{3}\right.$, and $\left.\mathrm{UO}_{2}\left(\mathrm{NO}_{3}\right)_{2}\right)$ and forms in soils on its bioaccumulation in Indian mustard and sunflower plants; (2) to investigate the relationship between $U$ solid phase distribution in soils as measured with sequential extraction, $\mathrm{U}$ bioaccumulation in plants and $\mathrm{U}$ partitioning in plant tissues; and (3) to assess the potential of sunflower and Indian mustard in phytoremediation of U-contaminated soils by estimating U removal efficiency. Both plants are widely distributed and planted in the USA and they have shown high bioaccumulation for toxic metals (Duquène et al. 2009; Véra-Tome et al. 2009; Adesodun et al. 2010; Laurette et al. 2012a; Jagetiya and Sharma 2013; Choudhury et al. 2016; Sharma et al. 2016).

\section{Materials and Methods}

\subsection{Chemical Agents and Plant Seeds}

We used guarantee reagent (GR) grade chemicals and reagents purchased from Scientific Fisher except for $\mathrm{U}$ $\left(\mathrm{UO}_{2}, \mathrm{UO}_{3}\right.$, and $\left.\mathrm{UO}_{2}\left(\mathrm{NO}_{3}\right)_{2}\right)$. The $\mathrm{UO}_{2}$ and $\mathrm{UO}_{3}$ were purchased from International Bio-Analytical Industries, Inc. and $\mathrm{UO}_{2}\left(\mathrm{NO}_{3}\right)_{2}$ was purchased from Poly Scientific R\&D Corp. The Indian mustard and Sunflower seeds were purchased from Ferry-Morse (USA). The preparation of nutrient solution according to Hoagland solution and $1 \mathrm{~L}$ solution consisted of $2.5 \mathrm{~mL} 202 \mathrm{~g} / \mathrm{L} \mathrm{KNO}_{3}+$ $2.5 \mathrm{~mL} 472 \mathrm{~g} / \mathrm{L} \mathrm{Ca}\left(\mathrm{NO}_{3}\right)_{2} \cdot 4 \mathrm{H}_{2} \mathrm{O}+1.5 \mathrm{~mL} 15 \mathrm{~g} / \mathrm{L} \mathrm{Fe}-$ $\mathrm{EDTA}+1 \mathrm{~mL} 493 \mathrm{~g} / \mathrm{L} \mathrm{MgSO}{ }_{4} \cdot 7 \mathrm{H}_{2} \mathrm{O}+1 \mathrm{~mL} 80 \mathrm{~g} / \mathrm{L}$ $\mathrm{NH}_{4} \mathrm{NO}_{3}+1 \mathrm{~mL} 2.86 \mathrm{~g} / \mathrm{L} \mathrm{H}_{3} \mathrm{BO}_{3}+1 \mathrm{~mL} 1.81 \mathrm{~g} / \mathrm{L}$ $\mathrm{MnCl}_{2} \bullet 4 \mathrm{H}_{2} \mathrm{O}+1 \mathrm{~mL} 0.22 \mathrm{~g} / \mathrm{L} \mathrm{ZnSO}_{4} \bullet 7 \mathrm{H}_{2} \mathrm{O}+1 \mathrm{~mL}$ 
$0.051 \mathrm{~g} / \mathrm{L} \mathrm{CuSO}_{4} \cdot 5 \mathrm{H}_{2} \mathrm{O}+1 \mathrm{~mL} 0.09 \mathrm{~g} / \mathrm{L}$ $\mathrm{H}_{2} \mathrm{MoO}_{4} \cdot \mathrm{H}_{2} \mathrm{O}+0.5 \mathrm{~mL} 136 \mathrm{~g} / \mathrm{L} \mathrm{KH}_{2} \mathrm{PO}_{4}$.

\subsection{Soil Sample and Experimental Design}

A soil sample was collected from the surface horizon $(0-30 \mathrm{~cm})$ of a paddy soil in Mississippi River Delta. After air-drying at room temperature, it was crushed, passed through a 2-mm mesh and homogenized. The soil $\mathrm{pH}$ was measured with a $\mathrm{pH}$ meter (Oakton, USA) in distilled water (1:5 w/v ratio), organic matter with $\mathrm{K}_{2} \mathrm{Cr}_{2} \mathrm{O}_{7}-\mathrm{H}_{2} \mathrm{SO}_{4}$ method (Han et al. 2007), and soil particle size distribution with the hydrometer method (Bouyoucos 1962).

$\mathrm{UO}_{2}, \mathrm{UO}_{3}$, and $\mathrm{UO}_{2}\left(\mathrm{NO}_{3}\right)_{2}$ were used as $\mathrm{U}$ sources at $100 \mathrm{mg} \mathrm{U} / \mathrm{kg}$ with $500 \mathrm{~g}$ soil in each beaker. Due to the disposal cost, only a small volume of contaminated soil was used for this study. A control without $U$ addition for both plants and a control with $100 \mathrm{mg} / \mathrm{kg} \mathrm{U}$ added in soil without plants were included. Each treatment was duplicated. After 1 month incubation at $80 \%$ of field capacity, 8-9 Indian mustard or sunflower seeds were planted in control and U-contaminated soils $(n=$ 16). During cultivation experiments of 3 months, soil water content was maintained at $80 \%$ of field capacity with distilled water and watered with nutrient solution twice a week with $10 \mathrm{~mL}$ Hoagland solution every time in a greenhouse under natural light at room temperature. At the end, plants were harvested for both shoots and roots and washed in $10 \mathrm{mM} \mathrm{Na}_{2} \mathrm{CO}_{3}$ and distilled water to remove $\mathrm{U}$ from root surface, and cleaned dust from shoot surface by distilled water. Shoots and roots were separated and dried at $85{ }^{\circ} \mathrm{C}$ for more than $12 \mathrm{~h}$ until constant masses. Soils and rhizosphere soils (near the root surface) in the beakers were air-dried at room temperature. Plant and soil samples were stored in a refrigerator at $4{ }^{\circ} \mathrm{C}$ prior to analysis and extraction.

\subsection{Chemical Analyses}

\subsubsection{Extraction of Potentially Bioavailable, Weak-Acid Soluble, and Labile $U$}

These forms of $U$ are potentially bioavailable to plants and microbes in soils. Extraction solutions were prepared as indicated by Smith et al. (2009). The potentially bioavailable, weak acid and labile $\mathrm{U}$ were extracted with $0.5 \mathrm{M} \mathrm{Ca}\left(\mathrm{NO}_{3}\right)_{2}$ solution $(\mathrm{pH} 5.09), 0.44 \mathrm{M}$ $\mathrm{CH}_{3} \mathrm{COOH}+0.1 \mathrm{M} \mathrm{Ca}\left(\mathrm{NO}_{3}\right)_{2}(\mathrm{pH} 2.75)$, and $0.014 \mathrm{M}$
$\mathrm{NaHCO}_{3}+0.0028 \mathrm{M} \mathrm{Na}_{2} \mathrm{CO}_{3}$ (pH 9.64), respectively. Briefly, about $1 \mathrm{~g}$ dry soil was weighed into $15 \mathrm{~mL}$ centrifuge tubes (Corning, USA) containing $10 \mathrm{~mL}$ of one of the prepared solutions and the tubes were shaken at $25{ }^{\circ} \mathrm{C}$ for $16 \mathrm{~h}$. Then tubes were centrifuged at $5480 \mathrm{rpm}$ for $15 \mathrm{~min}$ (5810R, Eppendorf, Germany). The supernatant was filtered through $0.45-\mu \mathrm{m}$ filter (Whatman, England) for U analysis with ICP-MS (Varian 820-MS, US).

\subsubsection{U Fractionation in Soils}

The sequential selective dissolution procedure (Han et al. 2007) was used for $U$ fractionation.

Step 1 - soluble plus exchangeable fraction (EXC)

Twenty-five milliliters of $1 \mathrm{M} \mathrm{NH}_{4} \mathrm{NO}_{3}$ with $\mathrm{pH}$ adjusted to 7.0 with $\mathrm{NH}_{3} \cdot \mathrm{H}_{2} \mathrm{O}$ was added into $50 \mathrm{~mL}$ polytetrafluoroethylene centrifuge tubes containing $1 \mathrm{~g}$ air-dried soil. The tubes were shaken for $30 \mathrm{~min}$ in a temperature controlled shaker at $25^{\circ} \mathrm{C}$, and then centrifuged at $5480 \mathrm{rpm}$ for $15 \mathrm{~min}$. The supernatant was poured out and filtered through $0.45-\mu \mathrm{m}$ filter for $\mathrm{U}$ analysis with ICP-MS. The soil residue was retained for the next step. The following extraction steps used the same centrifugation-decantation-filtration processes.

Step 2 - the fraction bound to carbonate (CARB)

Twenty-five milliliters of $1 \mathrm{M} \mathrm{CH}_{3} \mathrm{COONa}$ with $\mathrm{pH}$ adjusted to 5.0 with $\mathrm{CH}_{3} \mathrm{COOH}$ was added into the soil residue from Step 1. The tubes were shaken for $6 \mathrm{~h}$ at $25{ }^{\circ} \mathrm{C}$.

Step 3 - the fraction bound to easily reducible oxides (ERO)

This $\mathrm{U}$ fraction mostly bound to easily reducible oxides, such as Mn-oxides (Shuman 1982; Han et al. 2007). Briefly, $25 \mathrm{~mL}$ of $0.1 \mathrm{M} \mathrm{NH}_{2} \mathrm{OH} \cdot \mathrm{HCl}+0.01 \mathrm{M}$ $\mathrm{HCl}$ solution $(\mathrm{pH} 2.0)$ was added into the residue soil from step 2. The mixture was shaken for $30 \mathrm{~min}$ at $25{ }^{\circ} \mathrm{C}$.

Step 4 - the fraction bound to organic matter (OM)

This fraction mainly bound to soil organic matter (e.g., humic acid) and microorganisms. Three milliliters 
$\mathrm{H}_{2} \mathrm{O}_{2}+5 \mathrm{~mL} 0.01 \mathrm{HNO}_{3}$ was added into the residue soil from step 3 . The mixture was put into a water bath at $80^{\circ} \mathrm{C}$. After $2 \mathrm{~h}$, additional $2 \mathrm{~mL} \mathrm{H}_{2} \mathrm{O}_{2}$ were added into mixtures for one more hour in water bath at $80^{\circ} \mathrm{C}$. Then, $15 \mathrm{~mL} 1 \mathrm{M} \mathrm{NH}_{4} \mathrm{NO}_{3}$ was added and the tubes were shaken for $10 \mathrm{~min}$.

Step 5 - the fraction bound to amorphous iron oxides $(\mathrm{AmoFe})$

Twenty-five milliliters of $0.2 \mathrm{M}\left(\mathrm{NH}_{4}\right)_{2} \mathrm{C}_{2} \mathrm{O}_{4}+0.2 \mathrm{M}$ $\mathrm{H}_{2} \mathrm{C}_{2} \mathrm{O}_{4}$ buffer solution ( $\mathrm{pH}$ 2.89) was added into the residue soil from step 4 and shaken in a temperature controlled shaker for $4 \mathrm{~h}$ at $25^{\circ} \mathrm{C}$ in dark.

Step 6 - the fraction bound to crystalline iron oxides (CryFe)

Twenty-five milliliters of $0.04 \mathrm{M} \mathrm{NH}_{2} \mathrm{OH} \cdot \mathrm{HCl}+$ $25 \% \mathrm{CH}_{3} \mathrm{COOH}$ solution was added into the residue soil from step 5 and the mixture was heated in water bath for $3 \mathrm{~h}$ at $95^{\circ} \mathrm{C}$.

Step 7- the residue fraction (RES)

Twenty-five milliliters of $4 \mathrm{M} \mathrm{HNO}_{3}$ was added into the residue soil from step 6 and the mixture was heated in a water bath for $16 \mathrm{~h}$ at $80^{\circ} \mathrm{C}$ (Han and Banin 1997).

\subsubsection{Pseudo Total U Concentration}

The pseudo total $\mathrm{U}$ concentration was determined in soil after digestion with $\mathrm{HCl}-\mathrm{HNO}_{3}$ mixture (USEPA SW-846 Test Method 3050B), which may dissolve a majority of $\mathrm{U}$ especially potentially available portion (USEPA). $\mathrm{HCl}-\mathrm{HNO}_{3}$ has been widely used to extract the "total" metal in soils (USEPA). Briefly, $0.5 \mathrm{~g}$ soil sample was weighed into a $50-\mathrm{mL}$ polytetrafluoroethylene vessel with $4 \mathrm{~mL}$ of the mixing acids $\left(3 \mathrm{HCl}: 1 \mathrm{HNO}_{3}, \mathrm{v}: \mathrm{v}\right)$ and the mixture was heated on a hot block $\left(100{ }^{\circ} \mathrm{C}\right.$, Environmental Express Ltd.). At the end, extracts were filtered through $0.45-\mu \mathrm{m}$ membrane into $50-\mathrm{mL}$ glass flasks and filled to the mark with distilled water for the analysis of U with quadrupole ICP-MS. Uranium is free of polyatomic interference at high $\mathrm{m} / \mathrm{z}$ ratios. There are no known polyatomic ions that interfere in our solution. The detection limit of ${ }^{238} \mathrm{U}$ was $5 \mathrm{ng} / \mathrm{L}$.
All treatments for each plant and all extractions were performed in duplicates. All extraction and digestion experiments included two blank samples. A series of standards were analyzed every 30 samples to calibrate any shift of the instrument and the standards of $\mathrm{U}$ concentration were $0,5,10,25,50,75$, and $100 \mu \mathrm{g} / \mathrm{L}$.

\subsection{Determination of U Concentration in Plants}

Dried roots and shoots of plant samples were digested on hot block with wet acid digestion (McDaniel 1992; Han and Banin 1997). Briefly, 0.5 g plant samples were weighted into $50 \mathrm{~mL}$ polytetrafluoroethylene vessels with $6 \mathrm{~mL}$ concentrated $\mathrm{HNO}_{3}(65 \%)$ and $2 \mathrm{~mL} \mathrm{H}_{2} \mathrm{O}_{2}$ $(30 \%)$ for digestion until samples were completely dissolved. The digested solution was diluted to $40 \mathrm{~mL}$ with distilled water, filtered through $0.45-\mu \mathrm{m}$ filter and analyzed for U with ICP-MS, where U concentration should be below $100 \mu \mathrm{g}$ / (which was set for ICP-MS measurement). Blanks were prepared in the same way as the samples and each sample was duplicated.

\subsection{Data Processing}

$\mathrm{U}$ fraction (Ui) was determined by comparing $\mathrm{U}$ concentrations in extractant and soil mass, as follows:

$\mathrm{U}_{\mathrm{i}}(\mathrm{mg} / \mathrm{kg})=\frac{\mathrm{C}_{\mathrm{i}} \mathrm{V}_{\mathrm{i}}}{\mathrm{m}}$

where i was EXC, CARB, ERO, OM, AmoFe, CryFe or RES fractions of $\mathrm{U}$, $\mathrm{Ui}$ was the $\mathrm{U}$ fraction concentration in soil in $\mathrm{mg} / \mathrm{kg}, \mathrm{C}(\mathrm{mg} / \mathrm{L})$ was the $U$ concentration in extractant in $\mathrm{mg} / \mathrm{L}, \mathrm{V}$ was the extractant volume in $\mathrm{L}, \mathrm{m}$ was the soil mass for extraction in $\mathrm{kg}$, respectively.

$\mathrm{U}$ removal efficiency was determined by comparing $\mathrm{U}$ concentrations in plants and in soil, as follows:

$\mathrm{w}(\%)=\frac{w_{\mathrm{r}} m_{r}+w_{s} m_{s}}{C M} \times 100 \%$

where $\mathrm{w}(\%)$ was the $\mathrm{U}$ removal efficiency by plants in $\% ; \mathrm{w}_{\mathrm{r}}$ and $\mathrm{w}_{\mathrm{s}}$ were the $\mathrm{U}$ concentration in plant roots and shoots in $\mathrm{mg} / \mathrm{kg}$, respectively; $\mathrm{m}_{\mathrm{r}}$ and $\mathrm{m}_{\mathrm{s}}$ were the plant root and shoot weight in $\mathrm{kg}$; $\mathrm{C}$ and $\mathrm{M}$ were the $\mathrm{U}$ concentration in soils in $\mathrm{mg} / \mathrm{kg}$ and total soil mass in $\mathrm{kg}$, respectively.

Concentration factor $(\mathrm{CF})$ were ratios of $\mathrm{U}$ concentration in shoots over $U$ forms or total $U$ in soil and transfer factor $(\mathrm{TF})$ were ratios of $U$ concentrations in shoots over those in roots, as follows: 
$\mathrm{CF}=\frac{\mathrm{w}_{\mathrm{s}}}{\mathrm{C}_{\mathrm{i}}}$

$\mathrm{TF}=\frac{w_{s}}{w_{r}}$

where $\mathrm{w}_{\mathrm{s}}$ and $\mathrm{w}_{\mathrm{r}}$ were the $\mathrm{U}$ concentration in plant shoots and roots in $\mathrm{mg} / \mathrm{kg}$, respectively; $C_{i}$ was the soil total $U$, labile $\mathrm{U}$, weak-acid $\mathrm{U}$ or potentially bioavailable $\mathrm{U}$ in $\mathrm{mg} / \mathrm{kg}$. Microsoft Excel was used to calculate the U fraction content, removal efficiency, U content in plant samples and Origin 9.1 (OriginLab., USA) was used for figure processing. All treatments were duplicated. Average and standard deviations of analytical data were calculated with MS Excel and compared through the text. We used T-test for statistical analysis with MS Excel.

\section{Results and Discussion}

\subsection{Soil Properties}

The soil had a slightly alkaline $\mathrm{pH}$ of 7.57. After 3 months of the pot experiment, the soil $\mathrm{pH}$ increased depending on plant species and U sources (Table 1). pHs in $\mathrm{U}$ treated soils after a growing season did not show a significant difference between two plants (Table 1). The soil contained $2 \%$ organic matter, $2 \%$ sand, $42 \%$ silt, and $56 \%$ clay (silty clay). The actual $U$ concentrations in soil before the cultivation experiment with $\mathrm{UO}_{2}, \mathrm{UO}_{3}$ and $\mathrm{UO}_{2}\left(\mathrm{NO}_{3}\right)_{2}$ as $\mathrm{U}$ source were 98,82 and $72 \mathrm{mg} / \mathrm{kg}$ and at the end of growing season with $\mathrm{UO}_{2}, \mathrm{UO}_{3}$ and $\mathrm{UO}_{2}\left(\mathrm{NO}_{3}\right)_{2}$ as $\mathrm{U}$ source were 96,77 , and $68 \mathrm{mg} / \mathrm{kg}$, respectively. Thus, both $\mathrm{UO}_{3}$ and $\mathrm{UO}_{2}\left(\mathrm{NO}_{3}\right)_{2}$ showed a much higher solubility and bioavailability than $\mathrm{UO}_{2}$, demonstrating the importance of $U$ sources to phytoremediation efficiency.

Table 1 The $\mathrm{pH}$ of soil after cultivation of 3 months $(n=16)$

\begin{tabular}{lcccl}
\hline Plant species & $\mathrm{CK}$ & $\mathrm{UO}_{2}$ & $\mathrm{UO}_{3}$ & $\mathrm{UO}_{2}\left(\mathrm{NO}_{3}\right)_{2}$ \\
\hline Sunflower & 8.72 & 7.85 & 8.36 & $7.92 \mathrm{a}$ \\
Indian mustard & 8.38 & 7.39 & 8.46 & $8.67 \mathrm{a}$ \\
\hline
\end{tabular}

Plants with the same letter were not significantly different at the 0.05 probability level
3.2 The Potentially Bioavailable, Weak-Acid Soluble and Labile U in Soils

The potentially bioavailable $\mathrm{U}$ refers to $\mathrm{U}$ in soils easily available and directly used by plants and microbes, while weak-acid soluble and labile $U$ implies the potentially bioavailable $U$ in soil which is in equilibrium with bioavailable $U$. These forms of $U$ in soils had a great influence on U bioaccumulation (Tables 2 and 3) as indicated in previous studies (Xian 1989; Roy and McDonald 2015). Changes in three $U$ forms in soils depended on $\mathrm{U}$ sources, incubation and cultivation time and plant species (Fig. 1). The potentially bioavailable, weak-acid soluble, and labile U contents decreased with aging time, which may be caused by $\mathrm{U}$ adsorption in soil and further $\mathrm{U}$ redistribution among solid phase components, namely Fe-Mn oxides, soil organic matter and clay minerals (Han et al. 2007; Kowal-Fouchard et al. 2004; Wei et al. 2007; Dang et al. 2016). Statistical analyses indicated that planting and initial aging had significant effects in $\mathrm{UO}_{3}$ and uranyl treatments, but not in $\mathrm{CK}$ and $\mathrm{UO}_{2}$ treatments. Both aging and planting significantly decreased the bioavailable $\mathrm{U}$ and the labile $\mathrm{U}$ as well to some extent the weak acid soluble $\mathrm{U}$ in both $\mathrm{UO}_{3}$ and uranyl treatments compared to $\mathrm{U}$ in soils after 1 month with no plants. Significant differences were found among various $U$ species.

$\mathrm{U}(\mathrm{IV})$ as $\mathrm{UO}_{2}$ is sparingly soluble $\left(\log K_{\mathrm{sp}}=\right.$ - $53.93 \pm 0.2)$, while it may transform into U(VI) under oxidizing conditions in the presence of natural oxidants, such as $\mathrm{Fe}(\mathrm{III})$ and $\mathrm{O}_{2}: \mathrm{UO}_{2}+2 \mathrm{Fe}^{3+} \rightarrow$ $\mathrm{UO}_{2}{ }^{2+}+2 \mathrm{Fe}^{2+} ; \mathrm{UO}_{2}+1 / 2 \mathrm{O}_{2} \rightarrow \mathrm{UO}_{2}{ }^{2+}$. Due to its structure, the $\mathrm{UO}_{2}$ may persist for a long period of time in the oxidizing condition (Finch and Ewing 1992). Zielinski and Meier (1988) showed that the oxidation of $\mathrm{UO}_{2}$ was extremely slow under natural condition. Low bioavailability of $U$ from soils prepared using $\mathrm{UO}_{2}$ was evidenced by limited plant uptake (discussed later). For $\mathrm{U}(\mathrm{VI})$, the $\mathrm{UO}_{3}$ and $\mathrm{UO}_{2}\left(\mathrm{NO}_{3}\right)_{2}$ appeared as ionic forms in soil such as $\mathrm{UO}_{2}{ }^{2+}$ (many more anionic and cationic species) in oxidative conditions.

In comparison with bare soil, plant growth increased potentially bioavailable and extractable U. Labile and weak acid extractable $U$ from soils amended with $\mathrm{U}(\mathrm{VI})\left(\mathrm{UO}_{3}\right.$ and $\left.\mathrm{UO}_{2}\left(\mathrm{NO}_{3}\right)_{2}\right)$ especially in rhizosphere soils of Indian mustard increased (Fig. 1). Bioavailable $\mathrm{U}$ in soils with $\mathrm{UO}_{3}$ and $\mathrm{UO}_{2}\left(\mathrm{NO}_{3}\right)_{2}$ sources under Indian mustard were 
Table 2 Ratios of extractable $\mathrm{U}$ over soil total $\mathrm{U}$ and $\mathrm{U}$ concentration in plants tissues $(n=12)$

\begin{tabular}{|c|c|c|c|c|c|c|c|c|c|c|}
\hline \multirow[t]{3}{*}{ U sources } & \multicolumn{6}{|c|}{ Ratios of extractable U/soil total U } & \multicolumn{4}{|c|}{ U concentration $(\mathrm{mg} / \mathrm{kg})$ in } \\
\hline & \multicolumn{2}{|c|}{ Bioavailable U } & \multicolumn{2}{|c|}{ Weak-acid U } & \multicolumn{2}{|l|}{ Liable U } & \multicolumn{2}{|l|}{ Shoots } & \multicolumn{2}{|l|}{ Roots } \\
\hline & Sunflower & $\begin{array}{l}\text { Indian } \\
\text { mustard }\end{array}$ & Sunflower & $\begin{array}{l}\text { Indian } \\
\text { mustard }\end{array}$ & Sunflower & $\begin{array}{l}\text { Indian } \\
\text { mustard }\end{array}$ & Sunflower & $\begin{array}{l}\text { Indian } \\
\text { mustard }\end{array}$ & Sunflower & $\begin{array}{l}\text { Indian } \\
\text { mustard }\end{array}$ \\
\hline $\mathrm{UO}_{2}$ & NA & NA & NA & 0.001 & 0.02 & 0.02 & 0.71 & $2.56 \mathrm{a}$ & 7.98 & $3.29 \mathrm{a}$ \\
\hline $\mathrm{UO}_{3}$ & 0.02 & 0.06 & 0.15 & 0.26 & 0.57 & 0.62 & 4.08 & $19.1 \mathrm{~b}$ & 136 & $277 b$ \\
\hline $\mathrm{UO}_{2}\left(\mathrm{NO}_{3}\right)_{2}$ & 0.004 & 0.05 & 0.08 & 0.16 & 0.61 & 0.48 & 5.06 & $7.18 \mathrm{~b}$ & 167 & $184 b$ \\
\hline
\end{tabular}

NA not available as $U$ concentrations in soil below the detection limit

$\mathrm{U}$ concentrations within shoots or roots followed by different letters were significantly different at the 0.05 probability level among $\mathrm{U}$ species

higher than those under sunflower and bare soils (Fig. 1). Both weak acid extractable and labile $\mathrm{U}$ in soils with $\mathrm{UO}_{3}$ and $\mathrm{UO}_{2}\left(\mathrm{NO}_{3}\right)_{2}$ sources with both plants were higher than bare soils. This may be caused by root exudates/siderophores, and organic acids, especially in Indian mustard (Mench et al. 1988; Mench and Martin 1991; Yang and Pan 2013; Kim et al. 2010). Root exudate includes low molecular weight organic acids and phenols and high molecular weight polysaccharide and proteins, depending on plant species (Yang and Pan 2013; Baetz and Martinoia 2014). Yang and Pan (2013) reported that root exudates from sunflower had strong complexation propensity for metals, which indicates that root exudates may significantly influence bioavailability, toxicity, and phytoavailability of $U$ in soil. Kim et al. (2010) found that root exudates from Indian mustard increased soluble metals in alkaline soil. However, plant growth did not significantly affect solubility and bioavailability of U(IV) in soils amended with $\mathrm{UO}_{2}$.

\subsection{Redistribution of U Among Solid Phase Components}

The sum of $U$ in sequential steps was in agreement with the total $U$ extracted in the single step (Fig. 2). The relative error between the sum and the total was about $4.5 \%$, which indicates that our sequential selective dissolution technique gave a reasonable recovery. The OM (60-70\%) and AmoFe (0-30\%) fractions were the dominant solid phase fractions in $\mathrm{UO}_{2}$-contaminated soils with both sunflower and Indian mustard while the CARB (70-80\%) and OM (10-20\%) fractions were the major solid phase fractions for soils with $\mathrm{U}(\mathrm{VI})$ $\left(\mathrm{UO}_{3}\right.$ and $\left.\mathrm{UO}_{2}\left(\mathrm{NO}_{3}\right)_{2}\right)$ (Fig. 3). The $\mathrm{UO}_{3}$ polluted soils had $10 \%$ more OM and $10 \%$ less CARB fractions than soils with $\mathrm{UO}_{2}\left(\mathrm{NO}_{3}\right)_{2}$. This indicates that more soluble $\mathrm{U}$ (VI) such as soils with uranyl were bound in the CARB fraction than soils with less soluble $\mathrm{UO}_{3}$. However, insoluble $\mathrm{U}$ (IV) such as $\mathrm{UO}_{2}$ was bound to the $\mathrm{OM}$ fraction. This was reflected by the distribution of reduced, $\mathrm{U}(\mathrm{IV})$, species such as $\mathrm{UO}_{2}$ in soils that more

Table 3 Concentration factors and transfer factors of $\mathrm{U}$ in Sunflower and Indian mustard $(n=12)$

\begin{tabular}{|c|c|c|c|c|c|c|}
\hline \multirow[t]{2}{*}{ Plant species } & \multirow[t]{2}{*}{ U sources } & \multicolumn{4}{|c|}{ Concentration factor (Shoot-U/Soil-U), based on } & \multirow{2}{*}{$\begin{array}{l}\text { Transfer factor } \\
\text { Shoot-U/Root-U }\end{array}$} \\
\hline & & Soil total U & Liable U & Weak-acid U & Bioavailable U & \\
\hline \multirow[t]{3}{*}{ Sunflower } & $\mathrm{UO}_{2}$ & 0.01 & 0.49 & NA & 0.01 & 0.10 \\
\hline & $\mathrm{UO}_{3}$ & 0.05 & 0.09 & 0.36 & 0.05 & 0.03 \\
\hline & $\mathrm{UO}_{2}\left(\mathrm{NO}_{3}\right)_{2}$ & 0.07 & 0.12 & 0.76 & 0.07 & 0.03 \\
\hline \multirow[t]{3}{*}{ Indian mustard } & $\mathrm{UO}_{2}$ & 0.03 & 1.30 & 7.94 & NA & 0.78 \\
\hline & $\mathrm{UO}_{3}$ & 0.25 & 0.41 & 0.97 & 4.46 & 0.07 \\
\hline & $\mathrm{UO}_{2}\left(\mathrm{NO}_{3}\right)_{2}$ & 0.11 & 0.22 & 0.65 & 1.90 & 0.04 \\
\hline
\end{tabular}

NA not available as $\mathrm{U}$ concentrations in soil below the detection limit 

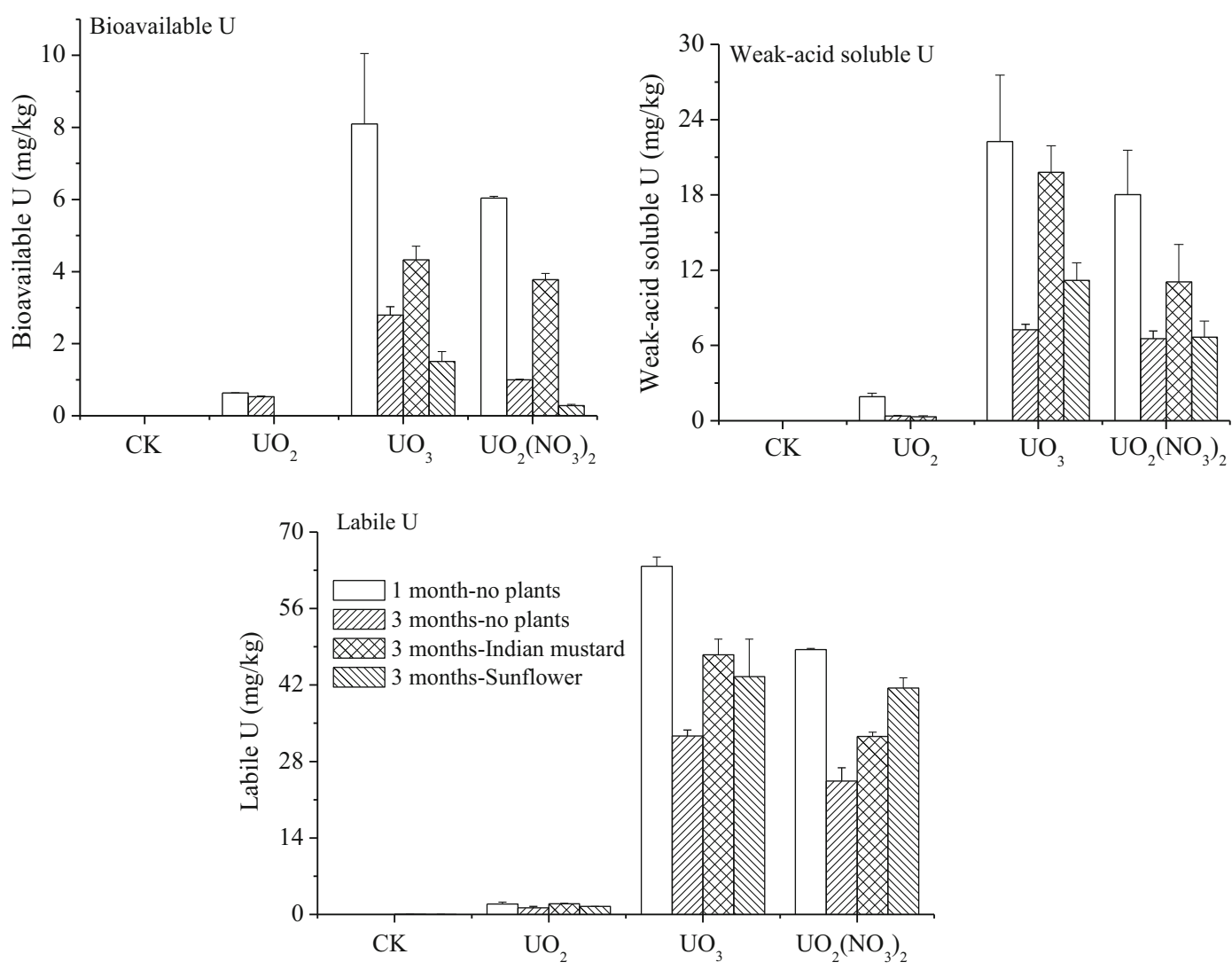

Fig. 1 Effects of Indian mustard and sunflower plants on U bioavailability in soil (as means of two replicate analyses and error bars were standard deviations)

$\mathrm{U}$ (IV) was present in the OM fraction. In part, low solubility of $\mathrm{U}$ (IV) (such as $\mathrm{UO}_{2}$ ) might be oxidized into $\mathrm{U}(\mathrm{VI})$ during the extraction with nitric acids and hydrogen peroxides.

Plant growth affected $U$ redistribution among solid phase components, especially for the EXC fraction of

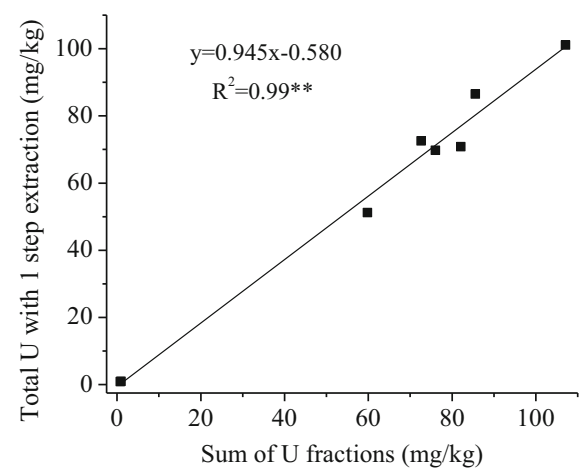

Fig. 2 Comparison of the total $U$ extracted with a single step acid and the sum of $U$ in solid phase components as extracted with sequential dissolution procedure. $* *$ Significant at the 0.01 probability level
$\mathrm{U}(\mathrm{VI})$ in soils prepared with $\mathrm{UO}_{3}$ and uranyl. Indian mustard growth solubilized more U(VI) than sunflower into the soluble and exchangeable fractions (Fig. 3). Plant root exudates (such as organic acid, polysaccharide, and proteins) increased the fraction of $U$ (VI) in soils as water-soluble and exchangeable forms (Mench et al. 1988; Yang and Pan 2013; Kim et al. 2010). Planting may also change soil properties such as $\mathrm{pH}$ (Table 1) which may also shift $U$ distribution among solid phase fractions.

The current study was in agreement with previous reports showing $U$ redistribution among fractions in soil was influenced by both $\mathrm{U}$ sources and plant species ( $\mathrm{Lu}$ et al. 2005; Jalali and Khanlari 2008; Mench et al. 1988; Mench and Martin 1991; Kim et al. 2010). In general, carbonate and organic matter were two important sinks for $\mathrm{U}$ in soils (Veeh et al. 1974; Bradl 2004; Weyer et al. 2008; Meng et al. 2017). Meng et al. (2017) reported humic substance extracted from leonardite showed a significant adsorption capacity for uranyl in water. 

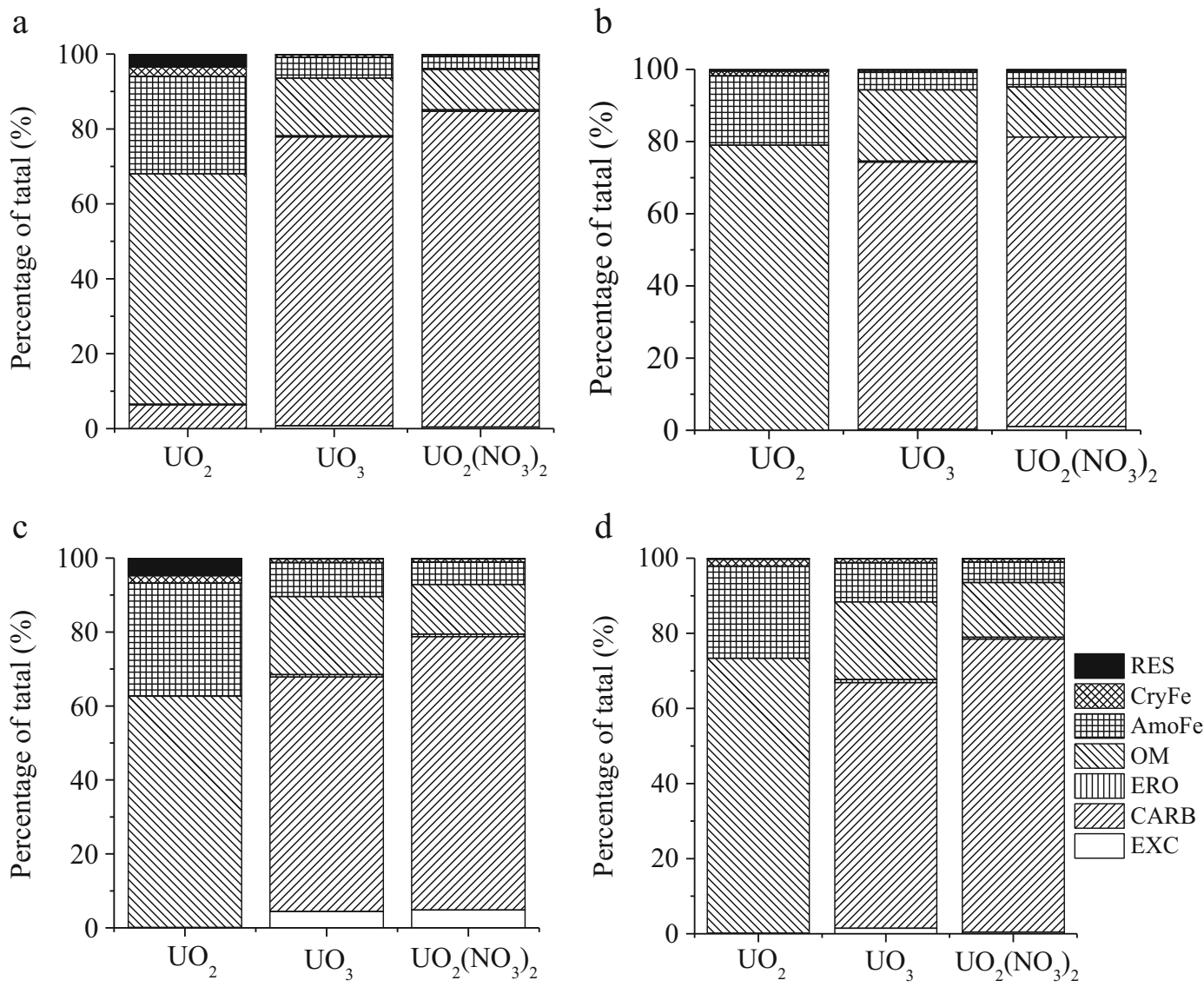

Fig. 3 The redistribution of $U$ among solid phase components in soils with aging time increased. a After 1 month, without plants and $\mathbf{b}$ 3 months, without plants, and $\mathbf{c}$ after 3 months with Indian mustard, and $\mathbf{d}$ sunflower (as means of two replicate analyses)

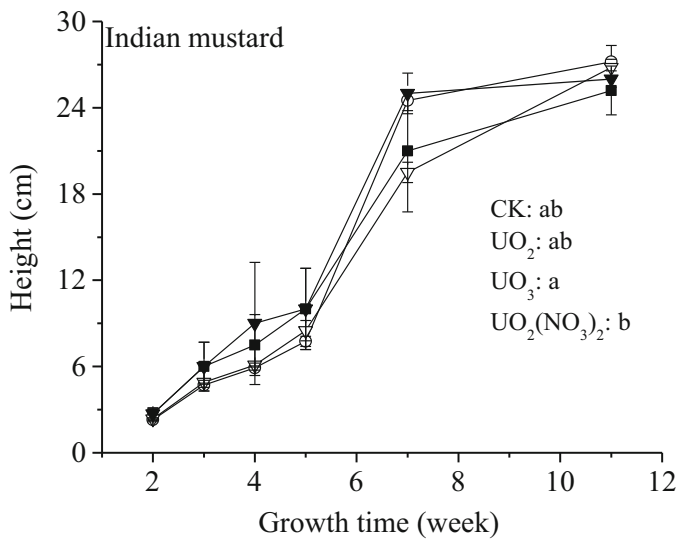

Fig. 4 The height $(\mathrm{cm})$ of Indian mustard and Sunflower plants in soil with various $U$ sources in the first 11 weeks (each treatment was duplicated. 3-5 plants grew in each pot). Heights were averages of all plants in two replicated pots for each $U$ form. Bars were standard deviations of all these plants

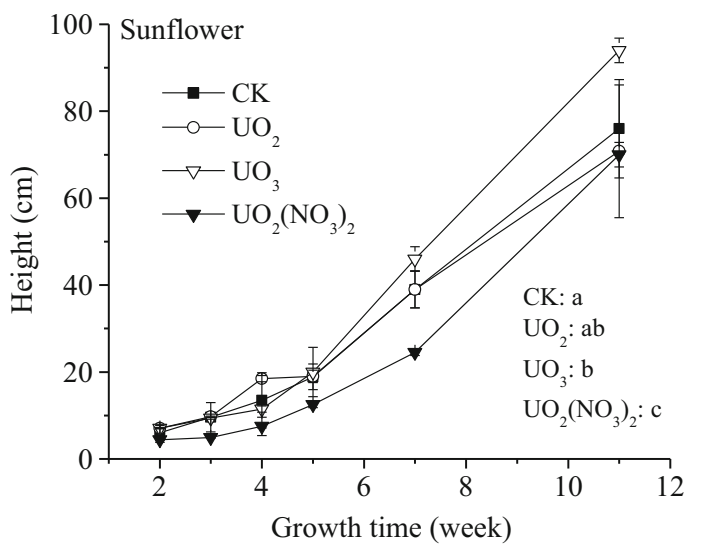

for two replicates. U species within Indian mustard or Sunflower followed by different letters were significantly different at the 0.05 probability level. (Four time series of plant heights for each individual plant species with all times were compared among various U species) 


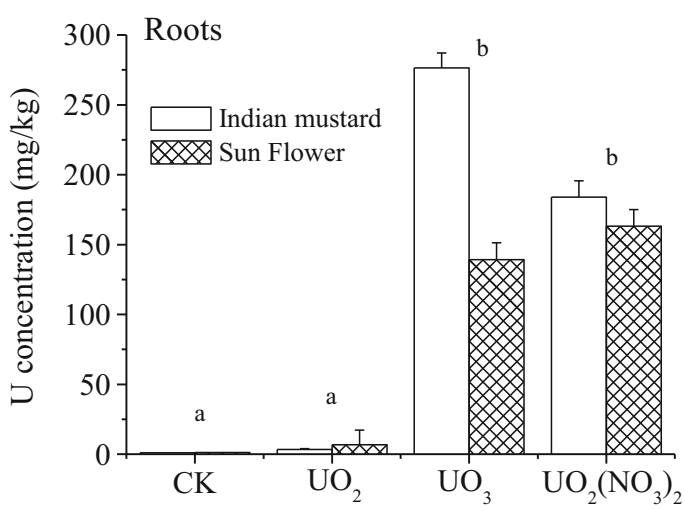

Fig. $5 \mathrm{U}$ uptake and bioaccumulation in shoots and roots of sunflower and Indian mustard from soils with different $U$ sources (as averages of two replicates for each treatment and bars as

\subsection{Phyto-Toxicity of U(VI) to Indian Mustard and Sunflower}

Two plants showed different tolerances to various $\mathrm{U}$ species in soils during their first 3-month growth. Young Indian mustard showed higher U(VI) tolerance than sunflower in soils prepared with U(VI) uranyl (Fig. 4). Sunflower displayed a significant higher phyto-toxicity of U(VI) in uranyl treatment (Fig. 4), as shown by a growth retardation (30-50\% decrease) compared to other $\mathrm{UO}_{2}$ and $\mathrm{UO}_{3}$ at first 7 weeks. This level of toxicity may be related to the tolerance/sensitivity of plant species and chemical toxicity of $\mathrm{U}$ in soil (Sheppard et al. 2005). At first 7 -week growth time, sunflower growth had only $50-70 \%$ of the plant shoot height in the control. Soils prepared with $\mathrm{UO}_{2}$ and $\mathrm{UO}_{3}$ did not show phytotoxicity in sunflower growth. However, phyto-toxicity of U(VI) disappeared in soils during sunflower maturation (Fig. 4), in part attributing to the aging $\mathrm{U}$ in soils, which decreased its solubility and bioavailability as well as increased tolerance in older plants (Figs. 1 and 3).

\subsection{The Uptake and Bioaccumulation of $U$ by Indian} Mustard and Sunflower

The uptake and bioaccumulation of $U$ by plants was significantly influenced by $\mathrm{U}$ sources used to prepare the current soil and plant species (Fig. 5). Both plants bioaccumulated more $\mathrm{U}$ in both shoots and roots from soils with $\mathrm{U}(\mathrm{VI})$ source $\left(\mathrm{UO}_{3}\right.$ and $\left.\mathrm{UO}_{2}\left(\mathrm{NO}_{3}\right)_{2}\right)$ than from soils with $\mathrm{U}(\mathrm{IV})\left(\mathrm{UO}_{2}\right)$ prepared soil. This was controlled by the solubility of $U$ compounds in soils.

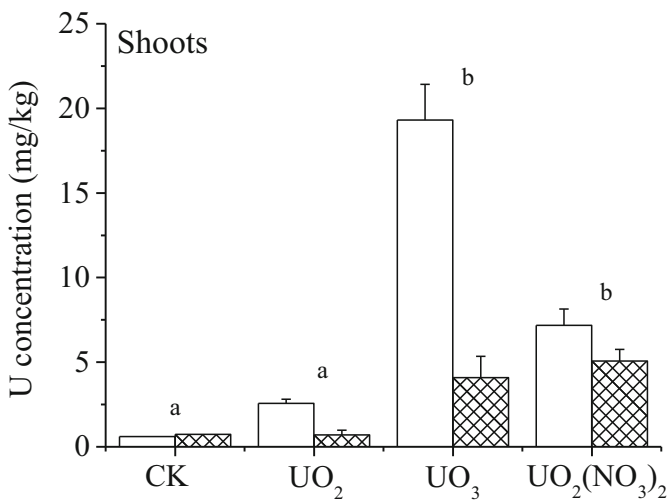

standard deviations). U species within roots or shoots followed by different letters were significantly different at the 0.05 probability level

$\mathrm{U}(\mathrm{IV})$ as $\mathrm{UO}_{2}$ was highly insoluble in soil, while $\mathrm{U}(\mathrm{VI})$ such as $\mathrm{UO}_{3}$ and $\mathrm{UO}_{2}\left(\mathrm{NO}_{3}\right)_{2}$ had higher solubility (Abdelouas 2006). $\mathrm{UO}_{3}$ was partly soluble and $\mathrm{UO}_{2}\left(\mathrm{NO}_{3}\right)_{2}$ was soluble in soils. However, both plants took up more $\mathrm{U}(\mathrm{VI})$ from partially soluble $\mathrm{UO}_{3}$ than from soluble uranyl (Fig. 4). This may be affected by two main reasons: (1) root exudates from both plants, which significantly increased solubility of $\mathrm{UO}_{3} ;(2)$ soil components, such as Fe-Mn oxides, minerals and humic substances, which sorb uranyl ionic (Mench et al. 1988; Kowal-Fouchard et al. 2004; Wei et al. 2007; Yang and Pan 2013; Kim et al. 2010; Dang et al. 2016; Meng et al. 2017). Moreover, Indian mustard has more abundant root systems and thus may have released more exudates than sunflower, resulting in higher solubility of U(VI) under Indian mustard (previous section) and higher uptake of $U$ from soils in this study.

\section{Conclusions}

In this study, three $\mathrm{U}$ sources $\left(\mathrm{UO}_{2}, \mathrm{UO}_{3}\right.$, and $\left.\mathrm{UO}_{2}\left(\mathrm{NO}_{3}\right)_{2}\right)$ were used to produce $\mathrm{U}$-contaminated soils in order to study bioaccumulation processes in Indian mustard and sunflower. Potentially bioavailable, weakacid soluble, and labile $\mathrm{U}$ decreased with time during growing seasons because of an aging effect on solubility. Both plant species and $U$ sources had influences on bioaccumulation of $U$ from soils prepared with these three $U$ forms. The redistribution of $U$ among solid phase components was influenced by $U$ sources, time and plant species. Phyto-enhancement of U solubility/ 
bioavailability in soil may be caused by root exudates, such as small molecular weight organic acids. Indian mustard showed higher shoot biomass, uptake, and bioaccumulation than sunflower, as well as a higher tolerance to uranyl phytotoxicity and an improved U solubility and bioavailability in soils with $\mathrm{UO}_{3}$. However, due to the disposal cost, only small volumes of contaminated soils were used for this study. Thus plant uptake and phytoremediation efficiency of $U$ may not be directly applied to fields due to sizes of soil amount. Field feasibility of phytoremediation of U soils with these two plants required further study.

Funding This study was supported by the U.S. Army Engineer Research and Development Center (W912HZ-16-2-0021), the U.S. Nuclear Regulatory Commission (NRC-HQ-84-15-G-0042 and NRC-HQ-12-G-38-0038) and the U.S. Department of Commerce (NOAA) (NA11SEC4810001-003499).

\section{References}

Abdelouas, A. (2006). Uranium mill tailings: Geochemistry, mineralogy, and environmental impact. Elements, 2(6), 335-341. Adesodun, J. K., Atayese, M. O., Agbaje, T. A., Osadiaye, B. A., Mafe, O. F., \& Soretire, A. A. (2010). Phytoremediation potentials of sunflowers (Tithonia diversifolia and Helianthus annuus) for metals in soils contaminated with zinc and lead nitrates. Water, Air, \& Soil Pollution, 207(14), 195-201.

Alsabbagh, A. H., \& Abuqudaira, T. M. (2017). Phytoremediation of Jordanian uranium-rich soil using sunflower. Water, Air, \& Soil Pollution, 228(6), 219.

Baetz, U., \& Martinoia, E. (2014). Root exudates: the hidden part of plant defense. Trends in Plant Science, 19(2), 90-98.

Bednar, A. J., Medina, V. F., Ulmer-Scholle, D. S., Frey, B. A., Johnson, B. L., Brostoff, W. N., \& Larson, S. L. (2007). Effects of organic matter on the distribution of uranium in soil and plant matrices. Chemosphere, 70(2), 237-247.

Bouyoucos, G. J. (1962). Hydrometer method improved for making particle size analyses of soils. Agronomy Journal, 54(5), 464- 465.

Bradl, H. B. (2004). Adsorption of heavy metal ions on soils and soils constituents. Journal of Colloid and Interface Science, 277(1), 1-18.

Choudhury, M. R., Islam, M. S., Ahmed, Z. U., \& Nayar, F. (2016). Phytoremediation of heavy metal contaminated buriganga riverbed sediment by Indian mustard and marigold plants. Environmental Progress \& Sustainable Energy, 35(1), $117-124$.
Cordeiro, C., Favas, P. J. C., Pratas, J., Sarkar, S. K., \& Venkatachalam, P. (2016). Uranium accumulation in aquatic macrophytes in an uraniferous region: relevance to natural attenuation. Chemosphere, 156, 76-87.

Dang, D. H., Novotnik, B., Wang, W., Georg, R. B., \& Evans, R. D. (2016). Uranium isotope fractionation during adsorption, (co)precipitation, and biotic reduction. Environmental Science \& Technology, 50(23), 12695-12704.

Dang, D. H., Wang, W., Pelletier, P., Poulain, A. J., \& Evans, R. D. (2018). Uranium dispersion from $U$ tailings and mechanisms leading to $U$ accumulation in sediments: Insights from biogeochemical and isotopic approaches. Science of the Total Environment, 610-611, 880-891.

Duquène, L., Vandenhove, H., Tack, F., Meers, E., Baeten, J., \& Wannijn, J. (2009). Enhanced phytoextraction of uranium and selected heavy metals by Indian mustard and ryegrass using biodegradable soil amendments. Science of the Total Environment, 407(5), 1496-1505.

Fathi, R. A., Matti, L. Y., Al-Salih, H. S., \& Godbold, D. (2013). Environmental pollution by depleted uranium in Iraq with special reference to Mosul and possible effects on cancer and birth defect rates. Medicine, Conflict and Survival, 29(1), 725.

Favas, P. J. C., Pratas, J., Mitra, S., Sarkar, S. K., \& Venkatachalam, P. (2016). Biogeochemistry of uranium in the soil-plant and water-plant systems in an old uranium mine. Science of the Total Environment, 568, 350-368.

Fetter, S., \& von Hippel, F. N. (2000). The hazard posed by depleted uranium munitions. Science \& Global Security, 8(2), 125-161.

Finch, R. J., \& Ewing, R. C. (1992). The corrosion of uraninite under oxidizing conditions. Journal of Nuclear Materials, 190, 133-156.

Fujiwara, K., Yamana, H., Fujii, T., \& Moriyama, H. (2003). Determination of uranium (IV) hydrolysis constants and solubility product of $\mathrm{UO}_{2} \cdot \mathrm{xH}_{2} \mathrm{O}$. Radiochimica Acta, 91(6), 345-350.

Gu, B., Yan, H., Zhou, P., Watson, D. B., Park, M., \& Istok, J. (2005). Natural humics impact uranium bioreduction and oxidation. Environmental Science \& Technology, 39(14), 5268-5275.

Han, F. X., \& Banin, A. (1997). Long-term transformations and redistribution of potentially toxic heavy metals in arid-zone soils. I: incubation under saturated conditions. Water, Air, \& Soil Pollution, 95(1), 399-423.

Han, F. X., Kingery, W. L., Hargreaves, J. E., \& Walker, T. W. (2007). Effects of land uses on solid-phase distribution of micronutrients in selected vertisols of the Mississippi River Delta. Geoderma, 142(1), 96-103.

Jagetiya, B., \& Sharma, A. (2013). Optimization of chelators to enhance uranium uptake from tailings for phytoremediation. Chemosphere, 91(5), 692-696.

Jalali, M., \& Khanlari, Z. V. (2008). Effect of aging process on the fractionation of heavy metals in some calcareous soils of Iran. Geoderma, 143(1), 26-40.

Kim, K. R., Owens, G., \& Kwon, S. L. (2010). Influence of Indian mustard (Brassica juncea) on rhizosphere soil solution chemistry in long-term contaminated soils: a rhizobox study. Journal of Environmental Sciences, 22(1), 98-105.

Kowal-Fouchard, A., Drot, R., Simoni, E., \& Ehrhardt, J. J. (2004). Use of spectroscopic techniques for uranium (VI)/ 
montmorillonite interaction modeling. Environmental Science \& Technology, 38(5), 1399-1407.

Larson, S. L., Ballard, J., Medina, V., Thompson, M., O'Connor, G., Griggs, C., \& Nestler, C. (2009). Separation of depleted uranium from soil. ERDC/EL TR-09-1, U. S. Army Engineer Research and Development Center, Vicksburg, MS.

Laurette, J., Larue, C., Mariet, C., Brisset, F., Khodja, H., Bourguignon, J., \& Carrière, M. (2012a). Influence of uranium speciation on its accumulation and translocation in three plant species: oilseed rape, sunflower and wheat. Environmental and Experimental Botany, 77, 96-107.

Laurette, J., Larue, C., Llorens, I., Jaillard, D., Jouneau, P. H., Bourguignon, J., \& Carrière, M. (2012b). Speciation of uranium in plants upon root accumulation and root-to-shoot translocation: a XAS and TEM study. Environmental and Experimental Botany, 77, 87-95.

Liu, B., Peng, T., Sun, H., \& Yue, H. (2017). Release behavior of uranium in uranium mill tailings under environmental conditions. Journal of Environmental Radioactivity, 171, 160-168.

Lu, A., Zhang, S., \& Shan, X. Q. (2005). Time effect on the fractionation of heavy metals in soils. Geoderma, 125(3), 225-234.

McDaniel, W. (1992). Sample preparation procedure for spectrochemical determination of total recoverable elements in biological tissues. In C. K. Smoley (Ed.), Methods for the determination of metals in environmental samples (pp. 2532). Boca Ranton: CRC Press Inc.

Mench, M., \& Martin, E. (1991). Mobilization of cadmium and other metals from two soils by root exudates of Zea mays L., Nicotiana tabacum L. and Nicotiana rustica L. Plant and Soil, 132(2), 187-196.

Mench, M., Morel, J. L., Guckert, A., \& Guillet, B. (1988). Metal binding with root exudates of low molecular weight. Journal of Soil Science, 39(4), 521-527.

Meng, F. D., Yuan, G. D., Larson, S. L., Ballard, J. H., Waggoner, C. A., Arslan, Z., \& Han, F. X. (2017). Removing uranium (VI) from aqueous solution with insoluble humic acid derived from leonardite. Journal of Environmental Radioactivity, 180(1-8).

Qi, F., Zha, Z., Du, L., Feng, X., Wang, D., Zhang, D., Fang, Z., Ma, L., Jin, Y., \& Xia, C. (2014). Impact of mixed lowmolecular-weight organic acids on uranium accumulation and distribution in a variant of mustard (Brassica juncea var. tumida). Journal of Radioanalytical and Nuclear Chemistry, 302(1), 149-159.

Radenković, M. B., Cupać, S. A., Joksić, J. D., \& Todorović, D. J. (2008). Depleted uranium mobility and fractionation in contaminated soil (southern Serbia). Environmental Science and Pollution Research, 15(1), 61-67.

Roy, M., \& McDonald, L. M. (2015). Metal uptake in plants and health risk assessments in metal-contaminated smelter soils. Land Degradation \& Development, 26(8), 785-792.

Rankin, D. W. (2008). CRC handbook of chemistry and physics, 88th edition. Boca Raton, Florida: Taylor \& Francis Group, pp. 14-17.

Sani, R. K., Peyton, B. M., Dohnalkova, A., \& Amonette, J. E. (2005). Reoxidation of reduced uranium with iron (III)(hydr) oxides under sulfate-reducing conditions. Environmental Science \& Technology, 39(7), 2059-2066.
Sharma, S., Singh, B., Thulasidas, S. K., Kulkarni, M. J., Natarajan, V., \& Manchanda, V. K. (2016). Evaluation of terrestrial plants extracts for uranium sorption and characterization of potent phytoconstituents. International Journal of Phytoremediation, 18(1), 10-15.

Sheppard, S. C., Sheppard, M. I., Gallerand, M. O., \& Sanipelli, B. (2005). Derivation of ecotoxicity thresholds for uranium. Journal of Environmental Radioactivity, 79(1), 55-83.

Shuman, L. M. (1982). Separating soil iron- and manganese-oxide fractions for microelement analysis. Soil Science Society of America Journal, 46(5), 1099-1102.

Smith, S. C., Douglas, M., Moore, D. A., Kukkadapu, R. K., \& Arey, B. W. (2009). Uranium extraction from laboratorysynthesized, uranium-doped hydrous ferric oxides. Environmental Science \& Technology, 43(7), 2341-2347.

Tuovinen, H., Vesterbacka, D., Pohjolainen, E., Read, D., Solatie, D., \& Lehto, J. (2015). A comparison of analytical methods for determining uranium and thorium in ores and mill tailings. Journal of Geochemical Exploration, 148, 174-180.

Vandenhove, H., Van Hees, M., Wouters, K., \& Wannijn, J. (2007). Can we predict uranium bioavailability based on soil parameters? Part 1: effect of soil parameters on soil solution uranium concentration. Environmental Pollution, 145(2), 587-595.

Veeh, H. H., Calvert, S. E., \& Price, \& N. B. (1974). Accumulation of uranium in sediments and phosphorites on the South West African shelf. Marine Chemistry, 2(3), 189-202.

Véra-Tome, F., Rodriguez, P. B., \& Lozano, J. C. (2008). Elimination of natural uranium and ${ }^{226} \mathrm{Ra}$ from contaminated waters by rhizofiltration using Helianthus annuus L. Science of the Total Environment, 393(2), 351-357.

Véra-Tome, F., Rodriguez, P. B., \& Lozano, J. C. (2009). The ability of Helianthus annuus L. and Brassica juncea to uptake and translocate natural uranium and ${ }^{226} \mathrm{Ra}$ under different milieu conditions. Chemosphere, 74(2), 293-300.

Wei, M., Liao, J. L., Liu, N., Zhang, D., Kang, H. J., Yang, Y. Y., Yang, Y., \& Jin, J. N. (2007). Interaction between uranium and humic acid (I): adsorption behaviors of U (VI) in soil humic acids. Nuclear Science and Techniques, 18(5), 287293.

Weyer, S., Anbar, A. D., Gerdes, A., Gordon, G. W., Algeo, T. J., \& Boyle, E. A. (2008). Natural fractionation of ${ }^{238} \mathrm{U} /{ }^{235} \mathrm{U}$. Geochimica et Cosmochimica Acta, 72(2), 345-359.

Winde, F., \& van der Walt, I. J. (2004). The significance of groundwater-stream interactions and fluctuating stream chemistry on waterborne uranium contamination of streams - a case study from a gold mining site in South Africa. Journal of Hydrology, 287(1), 178-196.

Xian, X. (1989). Effect of chemical forms of cadmium, zinc, and lead in polluted soils on their uptake by cabbage plants. Plant and Soil, 113(2), 257-264.

Yang, J., \& Pan, X. (2013). Root exudates from sunflower (Helianthus annuus L.) show a strong adsorption ability toward Cd(II). Journal of Plant Interactions, 8(3), 263-270.

Zielinski, R. A., \& Meier, A. L. (1988). The association of uranium with organic matter in Holocene peat: an experimental leaching study. Applied Geochemistry, 3(6), 631-643. 


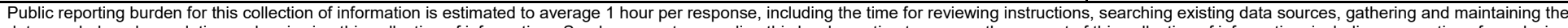

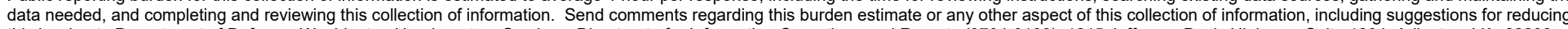

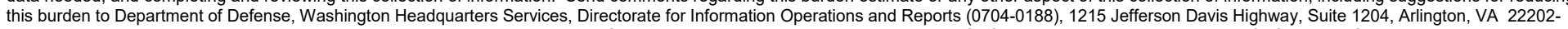

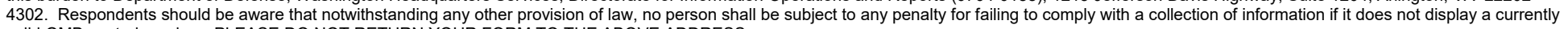
valid OMB control number. PLEASE DO NOT RETURN YOUR FORM TO THE ABOVE ADDRESS.
1. REPORT DATE (DD-MM-YYYY)
2. REPORT TYPE
3. DATES COVERED (From - To)

June 2020

\section{TITLE AND SUBTITLE}

Final

5a. CONTRACT NUMBER

Influences of U Sources and Forms on Its Bioaccumulation in Indian Mustard and Sunflower

5b. GRANT NUMBER

5c. PROGRAM ELEMENT NUMBER

$63372803 \mathrm{~F}$

6. AUTHOR(S)

Fande Meng, Decheng Jin, Kai Guo, Steven L. Larson, John H. Ballard,

Liangmei Chen, Zikri Arslan, Guodong Yuan, Jeremy R. White, Lixiang Zhou,

Youhua Ma, Charles A.Waggoner and Fengxiang X. Han

5d. PROJECT NUMBER

458170

5e. TASK NUMBER

5

5f. WORK UNIT NUMBER

\section{PERFORMING ORGANIZATION NAME(S) AND ADDRESS(ES)}

U.S. Army Engineer Research and Development Center

Environmental Laboratory

3909 Halls Ferry Road

8. PERFORMING ORGANIZATION REPORT

Vicksburg, MS 39180 NUMBER

ERDC/EL MP-20-6

9. SPONSORING / MONITORING AGENCY NAME(S) AND ADDRESS(ES)

Budget and Programs Div

Department of the Army USACE

441 G Street NW

Washington, DC 20314

10. SPONSOR/MONITOR'S ACRONYM(S)

USACE

11. SPONSOR/MONITOR'S REPORT NUMBER(S)

\section{DISTRIBUTION / AVAILABILITY STATEMENT}

Approved for public release; distribution is unlimited.

\section{SUPPLEMENTARY NOTES}

Originally published in Journal of Water air Soil Pollution, October 2018.

Collaborative work was conducted by the U.S. Army ERDC and Jackson State University via Cooperative Agreement W912HZ-16-2-002.

\section{ABSTRACT}

Anthropogenic activities, such as ore mining and processing, nuclear power generation, and weapon tests, have generated uranium (U) contamination to soils and waters. The mobility and bioavailability of $U$ are influenced by its sources, speciation, and plant species. Phytoremediation has emerged as an environmentally friendly, cost-effective green technology to remediate radioisotope-and metalcontaminated soils. The main objective of this study was to explore the feasibility using sunflower (Helianthus annuus) and Indian mustard (Brassica juncea) in cleaning up soils with $\mathrm{UO}_{2}, \mathrm{UO}_{3}$, and $\mathrm{UO}_{2}\left(\mathrm{NO}_{3}\right)_{2}$. Uranium was found to be bioaccumulated in plant roots more than plant shoots. Uranium uptake by both plant species was significantly higher from the $\mathrm{UO}_{3}$ - and uranyl-contaminated soils than from $\mathrm{UO}_{2}-$ contaminated soils. $\mathrm{UO}_{3}$ - and $\mathrm{UO}_{2}\left(\mathrm{NO}_{3}\right)_{2}$-contaminated soils showed higher exchangeable, weak acid extractable, and labile $\mathrm{U}$ than the $\mathrm{UO}_{2}$-contaminated soils. After a growing season, three $\mathrm{U}$ forms decreased as redistribution/transformation of $\mathrm{U}$ resulted in $\mathrm{U}$ species with lower extractability. This study indicates the importance of $U$ speciation in soil with regard to the potential use of sunflower and Indian mustard for phytoremediation of U-contaminated soils.

15. SUBJECT TERMS

Depleted uranium, U speciation, Redistribution, Plant species, Phytoremediation

\begin{tabular}{|l|l|l|c|c|c|}
\hline \multicolumn{2}{|l|}{ 16. SECURITY CLASSIFICATION OF: } & $\begin{array}{c}\text { 17. LIMITATION } \\
\text { OF ABSTRACT }\end{array}$ & $\begin{array}{c}\text { 18. NUMBER } \\
\text { OF PAGES }\end{array}$ & 19a. NAME OF RESPONSIBLE PERSON \\
\hline $\begin{array}{c}\text { a. REPORT } \\
\text { Unclassified }\end{array}$ & $\begin{array}{c}\text { b. ABSTRACT } \\
\text { Unclassified }\end{array}$ & $\begin{array}{c}\text { c. THIS PAGE } \\
\text { Unclassified }\end{array}$ & SAR & $\begin{array}{c}\text { 19b. TELEPHONE NUMBER } \\
\text { (include area code) }\end{array}$ & 14 \\
\hline
\end{tabular}

